УДК 821.164.41-3.09 Лазаревић, Л. https://doi.org/10.18485/msc50.2019.1.ch38

Милица Јакубјец Семковова

\title{
ВРСТЕ ХУМОРА У ЛАЗАРЕВИЋЕВИМ ПРИПОВЕТКАМА
}

Различити начини постизања комичких ефеката су већ описани у ранијим радовима на примеру одабраних приповедака. Анализа целокупног Лазаревићевог опуса у контексту начина приповедања може доказати ко је носилац хуморне интонације, у којим ситуацијима и у којој мери је то аутор.

Питање хумора које је предмет рада овогодишњег скупа, припада овим великим темама културе које нису често предмет научних истраживања иако је место хумора у људском животу непобитно. За своја даља разматрања изабрала сам дефиницију која гласи да је хумор „психичка диспозиција (стваралачка и пријемна) која дозвољава да се изразе разне појаве живота и уметности у категоријама комичности"'. Пољски речник књижевних термина додаје још благонаклоност и толеранцију а такође одсуство мржње, ругања и исмејавања. Мало шире објашњење налазимо у другом пољском речнику: „хумор је способност откривања смешних или апсурдалних елемената у идејама, ситуацијама, догађајима или поступцима", а речник српског језика тумачи да је то „доброћудно и лако исмејавање у озбиљном облику, ради увесељавања”.

Хумор припада категоријама које су обележене разним условима: друштвеним, историјским, културним, и такође везаним за људску јединку, психолошким. Смисао за хумор у односу на једног човека значи и интелигенцију и специфично перципирање стварности, таленат за опажање контраста или сличности у непредвиђеним ситуацијама; детаља који се не поклапају са целином, двосмислености ситуација, речи.

${ }^{1}$ M. Głowiński, T. Kostkiewiczowa, A.Okopień-Sławińska, Słownik terminów literackich, Wroclaw-Warsyawa-Kraków-Gdansk 1976, стр. 157-158.

2 W. Kopaliński, Słownik wyrazów obcych i zwrotów obcojęzycznych, Warszawa 1994, стр. 2118.

3 М. Московљевић, Речник савременог српског книжевног језика с језичким саветником, Београд 2000, стр. 726. 
Хумор није само добро расположење једног човека, он захтева ситуацију међуљудске комуникације. У књижевном делу ова комуникација постоји између аутора/приповедача и читаоца. Дакле сада се можемо приближити Лазаревићевим приповеткама.

У огромној литератури посвећеној делу најважнијег, најчитанијег до данас српског писца доба реализма питање хумора није досада комплексно обрађено. Кратко аналитичко поглавље везано за ову тему дао је Горан Максимовић у књизи Тријумф смијеха бавећи се само неким приповеткама и наглашавајући пре свега само једну врсту комичности: иронију и самоиронију. ${ }^{4}$ Ову специфику Швабице и Вертера приметили су такође многи ранији аналитичари Лазаревићевих приповедака. У обимној књижевној студији посвећеној писцу Јован Скерлић говори само о „исмејавању” немачке сентименталности ${ }^{5}$, Велибор Глигорић помиње само да је Лазаревић „носио у себи врло дискретан прамичак ироније”; Драгиша Живковић разматрајући пародично-хумористичке елементе у прози XIX века наглашава да „фина иронија... која прожима... цело дело Лазе Лазаревића... спасава аутора од депресивно-плачног, патетичног, па зато често и књишког, тона и израза"”. У опширном уводу у Изабрана дела Владимир Јовичић само у вези са Вертером пише о иронији, фарси и гротески ${ }^{8}$. Према Јовану Деретићу „хуморно-иронична стилска компонента” служи „као противтежа” идиличној слици сеоског живота или као начин неутрализације сентименталности у односу на хероје - интелектуалце. 9 „Иронично-каприциозну стилизацију” и „иронично-поетске слике или метафоре о срцу” помиње Душан Иванић ${ }^{10}$. Исте речи: иронија, хуморни тон, сарказам - без дубље анализе ових елемената у

${ }^{4}$ Г. Максимовић, Психолошка проза (Лаза Лазаревић) у: Тријумф смијеха. Комично у српској књижевној прози од Доситеја Обрадовића до Петра Кочића, Ниш 2003, стр. 147-150.

${ }^{5}$ J. Скерлић, Лаза К. Лазаревић, Књижевна студија, у: Писиц и књиге III, Београд 1964, стр. 82.

${ }^{6}$ В. Глигорић, Лаза К. Лазаревић, у: Српски реалисти. Београд 1956 стр. 147.

7 Д. Живковић, Пародично-хумористички стилски елементи као творачки принцип у српској прози ХІХ века, у: Европски оквири српске књижевности, Београд 1970, стр. 205.

${ }^{8}$ В. Јовичић, Приповетке Лазе К. Лазаревића, у: Л. Лазаревић, Изабрана дела. Београд 1981, стр. V-XXXV.

9 J. Деретић, Историја српске књижевности. Четврто издање, Београд 2004, стр. 833.

10 Д. Иванић, Незамјенльво дјело (Приповјетка Лазе К. Лазаревића), у: Свијет и прича. Београд 2002, стр. 243-264 (библиографија о писцу). 
Лазаревићевом делу - налазимо у радовима Манфреда Јенихена и Горане Раичевић. ${ }^{11}$.

Прво питање које се односи на хумор у Лазаревићевим приповеткама је: ко се смеје, или: ко хоће да нас, читаоце, увесељава и насмеје, ко је носилац хумористичке интонације.

Приповедачи у већини текстова, објављених и необјављених током живота, припадају средини коју описују, ${ }^{12}$ може се рећи да су репрезентативни за сеоско или малограђанско друштво. Када су изразити (као у На бунару, Школској икони, Први пут с оцем на јутрене, У добри час хајдуци, Он зна све) и описују конкретне догађаје, смисао за хумор се види пре свега у избору разних ситница - у ситуацијама, ликовима, речима. Друкчије је када хероји причају о себи: као Мишо из Швабице пишући писма својем побратиму и Јанко у Ветру описујући важну епизоду свог живота. У оба случаја приповедач - и истовремено херој, бира одређен начин приповедања, у оба случаја то је мање или више ироничан став према себи и свету. Приповедач Швабище хоће да разведри свог побратима и најављује: „Развићу сву своју музу. Тим ће бити смешније” Али „смешно” значи овде „самоиронично”. У Швабищи - што је доказао Г. Максимовић - иронија и самоиронија су главне детерминанте текста, усмереног против сентименталних крајности романтизма и стилском маниру који у романтичарској књижевности служи описивању претераних осећања и бујне маште. Мишо, берлински студент медицине служи се иронијом да би дао на тај начин отпор својим великим емоцијама, љубави према Немици - Ани. У опису ситуације која почиње да личи на велику љубавну сцену, аутор - приповедач намерно бежи од патетике. Мишо и Ана седе у салону: „По ноћи се било приближавало и вампири су чекали да се минутна сказаљка на сахату помакне за један чеперак, те да дигне поклопце с њихових ковчега. Бледог месеца није било. (Штета!...) (стр. 17). Аутор писама сам покушава да омаловажи осећање љубави. Ова иронија се најјаче види у XI и XII писму. Преокрет наступа - и то

${ }_{11}$ M. Jähnichen, Берлинске године Лазе Лазаревића у: Научни састанак слависта у Вукове дане 31/2, Београд 2003, стр. 98-99 и Г. Раичевић, Мотив страног у приповеткама Лазе Лазаревића, у: Научни састанак стависта у Вукове дане 31/2, Београд 2003, стр. 145.

12 Писала сам о њима у чланку Лазаревићеви портрети жена, у: Научни састанак слависта у Вукове дане 31/2, Београд 2003, стр. 133-134.

13 Л. Лазаревић, Швабица, у: Л. Лазаревић, Изабрана дела, Предговор и избор Владимир Јовичић, Београд 1981, стр. 17. Пошто ћу се и даље служити овом књигом, број странице ћу стављати у наводницима у тексту. 
је доказ Лазаревићеве уметничке вештине - у последњем писму у којем влада меланхолија.

Неке црте самоироније налазимо такође у Ветру. Аутор у првој реченици наглашава да ће ову причу причати неки Јанко који се са неке временске дистанце сећа своје велике љубави на први поглед. Самоиронички каже нпр. да се први поглед девојке „спуштао кроза ме и слазио на читав хват у земљу. Ја сам бар осећао горе на темену рупу и доле за патос заковане ноге. И онда сам се знојио, кухао, топио и напослетку био хладан ка леденица" (стр. 230). Кад хоће да сакрије своја осећања пред мајком, „трпа цигару у уста и тражи жигице док ... она [мајка] напослетку не изброја седам кутија, које су ... стајале под носом на ... писаћем столу" (стр. 236). Друга ситуација која ставља хероја у ироничко светло - цитирана у чланку Г. Максимовића - је кад потпуно збуњен сусретом са Ђорђем Јанко моли: „Ох, Боже, ти који си свемогући; ти који си васкрснуо Лазара и који чак од воде начиниш вино! Ти! Ти ми одрежи језик! Нећеш! Е, Хвала ти бар што си ми послао помоћника" (стр. 213). Карактеристику Јанка допуњује сцена опраштања при одласку слепог Ђорђа и вољене девојке, његове кћери. Он се рукује не само са гостима већ и са својом мајком која „озбиљно смешећи се” каже: „Збогом, али ја само до врата!" (стр. 244)

Пародистичка стратегија у Вертеру усмерена је према бесмисленом подражавању вертеризма. Свезнајући приповедач не припада описиваном свету. Од почетка се јавља као човек са смислом за хумор. Вертер почиње од поређења бање и рата - припремају се годинама, троше се „без рачуна и интереса” огромне паре, „живи се на парче” а на крају „прави се са непријатељем, односно са женом, уговор мира, после се приступа смањивању плате чиновницима и тоалете жени" (стр. 151). После оваквог увода можемо се надати и следећим хумористичким ефектима. Сажето и са суптилном иронијом приповедач кратко излаже садржину Гетеовог романа. Његов херој је „неко сањало” који се „одмах заљуби” у Лоту заручену „с неким Албертом”. „Једном - кад је већ удата - [...] спопадне је љубити али већ после тога није му остало ништа друго него да се убије. Он збиља напише, као што се то обично ради, много писама, погори своје хартије, напуни пиштољ, потегне и убије се” (стр. 179). Кулминација исмевања вертеризма наступа кад Младен - муж Марије у коју се заљубио херој ове приповетке - прича о овом роману и погрешно именује Гетеове јунаке. Ову сцену цитира Г. Максимовић ${ }^{14}$.

14 Г. Максимовић, стр. 149. 
Као допуна критичне слике романтичарске (а можда само популарне, петпарачке?) књижевности може се сматрати нпр. опис необичног утиска који остављају Маријине црне очи: „Само их погледаш, а пред тобом изничу као из земље шаркије, јатагани, бесни коњици што носе у друге крајеве лепе девојке на крилу јунакову, мандолинате, ханџари, дуели". Одмах после овог описа, у истој реченици наступа промена односа према овоме свету „и сва ова чуда што се причају у јужним приповеткама” (Вертер, стр. 156). Још смешније звуче „гатке из детињства” којих се сећа Јанко из Ветра: „о доктору који се дао исецкати на парчета, па закопати у ђубре, и кога су после нашли живог и здравог...”. Сам каже на крају да је то „сто којекаквих будалаштина” (стр. 220).

О иронији се може говорити такође у односу на наслове неких приповедака. Не може се озбиљно рећи да су хајдуци очекивани гости и долазе у добар час. Вишезначан је наслов Он зна све - ове речи понавља млада простодушна жена дубоко уверена да је њен муж идеал а она само његов ехо (не до краја тачан). Горко звучи наслов приповетке Све ће то народ позлатити. Невидљив, објективан приповедач гради атмосферу од сањивог очекивања лађе, са ситним хумористичким детаљима у опису пристаништа и људи, преко кулминације (долазак тешко рањеног војника) до тужног, скоро трагичног епилога. Наслов приповетке поновљен на крају текста - звучи једнозначно иронично.

Међутим иронички елементи су у другим Лазаревићевим приповеткама прилично ретки, само један пример ипак треба да се наведе. У На бунару током вечере (за столом седе само мушкарци и стара Радојка) ђеда заповеда да сви треба да слушају Аноку. Чувши ово решење она „као помамна улете женама у кухињу: - Јесте ли чуле, ви? Жене, па да не чују!” (стр. 144) - коментарише приповедач.

У већини Лазаревићевих приповедака комичност се јавља поред главног тока приповедања, некако „уз пут”, у многим детаљима. Прву групу чине комични догађаји, мале сцене, које не утичу на основни ток приче. У приповеци Први пут... у којој се успомене приповедача односе на озбиљне, чак и трагичне догађаје, у најтежем моменту - пропасти читаве породичне имовине - „Ђокица у авлији везао мачки џезву за реп па се увесељава њеном трком" (стр. 68). То је једини прамичак безбрижне веселости. У Школској икони кад је стари сеоски свештеник у свечаним хаљинама дошао у варош тада су „лупала ... сва звона и пуцале прангије, јер коњаник ... помисли да је владика" (стр. 90). Арсен, херој приповетке На бунару се први пут у животу од жалости опио. „Хтеде да удари ... себе по колену, али песница, без његова питања и одобрења лупи о пањ. За казну, он је тури у зубе и уједе је” (стр. 136). У Вертеру смешно је прика- 
зан долазак Марије са мужем у бању (Младен се четвороношке извуче из кола, „место на јармац, ступи ногом на ждрепчаник, посрну напред, одби руком од коњских сапи и сасвим неспретно скочи на земљу” стр. 156) и сцена за столом са збуњеним Јанком („Супу све му се чини да и сувише срче. Вино кад пије, чини му се да му здраво клокће” стр. 166-167). Херој и комична је сцена битке ђака описана на почетку приповетке Он зна све: „Ђокица, који је био врло мудар цар и врло пажљив војсковођа, склони гро̂ своје војске у кошару, у његовој авлији, и само нас је појединим деташованим одељењима иза дрвљаника и стрељачким ланцем иза тарабе узнемиравао" и тако даље (стр. 247-248).

Другу групу хумористичких елемената чине карактеристике хероја, нарочито из другог плана. У другом писму Швабице Мишо представља своје сустанаре. Дон Карлос, „ужасна противречност имену”, са великом црвеном марамом која стално вири из џепа, по цео дан чита новине и коментарише вести, па подвлачи ревносно све што му се чини најважније, бришући нос. „Тим исподвлаченим новинама обично повезује баба сутрадан ћупове с компотом" (стр. 7). Ова карактеристика се даље приближава карикатури: „како уђе на врата, чујеш како му се мућка пиво по трбуху" (стр. 7). У првој презентацији Аноке, јунакиње На бунару, приповедач се служи књижевном хиперболом: „А у Бурмаза је кћи - и по! Да пројашеш, што кажу, поред ње, па да она превали оним пустим очима, очас ти мркне свест, и једва се држиш на коњу" (стр. 133). Понашање кума Нинка у Београду (хоће чорбу да једе из чиније да не би прљао тањир) је пример „комике разлика” између села и града (Школска икона). Међу ликовима другог плана у Вертеру издваја се поручник Васиљевић, „необично леп и стасит” који се труди да „му ко каже да је ђаво и обешењак”, „држи да је сав свет 'глуп као чизма', а своју је каријеру почео од чешагије” (стр. 153). Комичност основану на контрасту Лазаревић користи у спољашњем портрету капетана у приповеци Све ће то народ... „аљкава униформа, а као снег бела кошуља и као млеко чиста сабља". Контрасти се такође тичу карактера овог човека „од кога ишчекујеш да зна аранжирати кадрил и очистити остригу, а опет те нимало не би изненадило кад би он окренуо дами леђа, обрисао нос салветом, или чак забо̂ виљушку у локумиће" (стр. 202). На потпуно далеком плану је у истој приповеци приглупи слуга у механи назван „прљаво створење”, и учитељ са ногом од стола као оружијем у У добар час...

Трећа група комичких ефеката у Лазаревићевим приповеткама је хумор заснован на игри речи.

Једна од појава овог типа је хумористички дијалог. Најсмешније, иако предмет овог разговора није нимало весео - звучи дијалог између 
капетана и Благоја чекајућих на пристаништу: „Јесте ли видели онога с ногом? - Кога с ногом? - Та онога без ноге? - Кога без ноге? - Та онога са штаком? - Кога са штаком? - Са штаком! Овога што су му доктори одсекли ногу? - А што су му одсекли? - Па, кажу, хтео је да умре од ране...” (Све ће то народ...стр. 205). У дијалог између Живка и хајдука који су упали ноћу у кућу исто тако се уплиће иронија: „Добро нам вече! - каже осорно овај човек [хајдук]. ... Живко цикну: „Зло ће ти бити, ако Бог да̂” (У добар час хајдуци стр. 126). Лако и са хумором разговара Мишо са Аном која моли: „Немојте да ласкате. - Хоћете да кажете: немојте ни одсад да ласкате као што ни досад нисте ласкали?” (Швабица, стр. 10).

У хумористичким поређењима Лазаревић се служи неочекиваним изборима, прескаче границе што чини поређење хиперболичким. Апотекар Катанић у Вертеру зна како ће и шта испричати Маријином мужу о њеним контактима са Јанком, „али га од тога задржа ... његова нарав, јача од Европе" (стр. 183). Поручник Васиљевић метафорички изражава свој занос Маријиним очима: „Па оне очи! Чиста арапска крв!” (стр. 157). Неочекивана је комичност заснована на малограђанском начину мишљења у опису „тепелука” који носи на глави жена Маринка магазаџије, „који тако безазлено блисташе, као да је Зајечар процватио, а кроз Књажевац протекла река од млека" (Све ће то народ.. стр. 201) ${ }^{15}$. Овај пример може да служи као доказ како је хумор условљен историјским околностима. Јован Скерлић пише: „Није довољно ставити примедбу да су Зајечар и Књажевац градови у Србији; ако се не дода да се прича дешава у рату 1876, када су оба места страдала, цела реченица губи сав ефекат"16. Али Скерлић не види овде парадоксалан хумор... У Швабици приповедач наводи стереотип: „Смешим се и тарем руке ко̂ Чифути кад подвале стари шешир под нов” (стр. 33). У Вертеру се још једном појављује „златна мисао” везана за бању: „Као што веле да вашар не може бити без кише и Цигана, тако ни бања се не може замислити без карташа" (стр. 153). Поређење „занесеног” Јанка - Вертера до „осетљиве даме кад види жабу” (Вертер, стр. 169) допуњује карактеристику овог хероја.

Анимизације и антропоморфизације су следећа средства изазивања смеха. Да би описао летњу врућину приповедач најављује: „Управо ми изгледа цела природа клонула, обезнанила се, исплазила језик па дакће” (У добар час хајдуци, стр. 121). У Ветру у соби пуној дима од цигара „ше-

15 Г. Максимовић, стр. 150.

16 J. Скерлић, Приповетке Лазе К. Лазаревића. Свеска I. Издане Српске кюижевне задруге, у: Ј. Скерлић, Писии и кюиге. III. Приредио Мидхат Бегић, Београд, 1964, стр. 74. 
талица од сата као да се лактовима гурала кроз дебео дим" (стр. 242), у Вертеру „сунце се залуд мучи да убаци и један зрачић” (стр. 167) у собу са прозором застрвеним дебелим завесама, а у опису прљаве механе привлачи пажњу „дрвена столица са сламним седиштем и сломљеном и тако живописно испруженом ногом, као да хоће да се фотографише" (Све ће то народ позлатити, стр. 204).

Међу типичне игре речи спада нпр. „погрешна” и одмах исправљена реченица из Швабище: „више ми не дршће лице и не горе груди, тј. не дршћу груди и не гори лице, како ли се каже?” (стр. 33). Састављање супротности је следећи начин коришћења игре речи: „човек са широким грудима и тесним ципелама" (Вертер, стр. 153) - Јанко - Вертер предаје се, према своме мишљењу „дубокој студији о животу, а у самој ствари сасвим плиткој љубави" (стр. 168). Сличан ефекат достиже приповедач у недовршеној приповеци Вучко: „ННајвећа добродетељ је бити истинољубив' говорио је наш хроми и стари поштар Марко отпечатавајући усијаном иглом туђа писма”" ${ }^{17}$ Мишо из Швабице пише пријатељу: „Мене је мимоишла чаша ... слађа од оне коју служе у Гетсиманском врту. Ђаво ме је терао, два-трипут сам лапнуо да сркнем из ње, но мој добри, геније држао ме је за ғушку" (стр. 32). У типичне игре речи спадају такође оваква духовита запажања као о младим људима „с чашама у руци, а у самој ствари с вином у глави” (Вертер, стр. 169) и о „дечку с тврдим земичкама и капетаници с бајатим лицем" (Све ће то..., стр. 201), а такође озбиљно обећање које даје Мишо своме побратиму: „дајем ти реч да ћу одсад спавати као топ и да нећу ништа сањати" (Швабица стр. 31).

Смешно је такође, да на крају овог списка хумора заснованог на игри речи, наведемо муцање једног од главних јунака приповетке У добар час хајдуци. Нешто више од смеха, можда и сажаљење, изазивају евидентне глупости које причају госпођа Ведел у Швабици и млада Велинка у приповеци Он зна све.

Типично књижевни карактер има још један, карактеристичан фин начин изазивања веселости. То је често употребљавање речи у наводницима. Највише их има у Швабици и Ветру где у вези са овде владајућом тежњом критичке расправе са романтизмом Лазаревић даје иронички смисао типичним романтичарским епитетима и метафорама које се могу третирати као псеудоцитати. Поред наведених у Максимовићевим тексту што су: „свиона косица”, „порумењене и побледеле обрашчиће”, „лепе ручице да их провучем кроз иглене уши”, „слатка туга и тужно ве-

17 Л. Лазаревић, Вучко, у: [Л. Лазаревић,] Приповетке Л. К. Лазаревића. Свеска друга. Српска књижевна задруга, Београд, 1899, стр. 214. 
сеље”, „жуборећи поточић” (из Швабице) може се још додати „болујем од случаја”, [небо] „плави од истока”, „значајан поглед”, „сруших небеске сводове" (из Ветра). Сентиментално порекло имају за главног хероја - приповедача такође овакве речи како „срце”, „разум” (једна реч поред друге), „филозофисање”, „хладно судим”, „дођем у ватру” - оне су такође стављене под наводнике. Приповедач - главни јунак Швабице се јавно дистанцира од сентимената. Уз „поток суза и уздисаја” додаје своје ироничко поређење: „дубоких коิ артески бунар и дугачких ко̂ Трифко јекмегџија”, а после поређења „жарке очи као небо” следи допуна „разуме се италијанско" (стр. 32). Недостатак овог типа псеудоцитата у Вертеру може се тумачити другим начином приповедања - интертекстуални дискурс са романтизмом води се помоћу других средстава - на вишем нивоу организације текста, преко догађаја и хероја.

У Ветру постоји још једна група речи и реченица под наводницима. То су речи Јанкове мајке која се служи старинским начином причања и уплеће у свој говор „народну мудрост” као нпр.„све са светом и кад је чему време". Ову ће златну мисао користити писац још у недовршеној приповеци Стојан и Илинка. ${ }^{18}$

Приближавајући се закључку треба да се вратимо основном питању: какав је Лазаревићев смисао за хумор? Без сумње може се рећи да се поред ироније Лазаревић чешће и ефикасније служи правим хумором, финим, тананим и доброћудним. У свету приказаном у приповеткама, међу Србима друге половине XIX века, често влада смех; хероји се смеју, смешкају, насмехују, уста им се развуку од смеха, прсну у смех, громогласно се смеју и тресу се од смеха, завраћају од смеха, слатко и добродушно се насмевају, деца у игри умиру од смеха. Лазаревић чак зна да покаже како се смеје врло озбиљан чак намћораст човек, отац приповедача Први пут са оцем на јутрење: кад „оцу даде нешто на смех, па неколико пута развуче мало леву страну од уста и ока левога ока набра му се кожа" (стр. 56). Хероји приповедака не исмевају, не ругају се другим. Питање да ли је то типичан српски смисао за хумор (као нпр. „енглески хумор”, „чешки хумор”) није предмет мог излагања. Да ли је ова здрава Лазаревићева веселост заразна, да ли се преноси на читаоце почетка XXI века, то је друго питање.

18 Л. Лазаревић, Стојан и Илинка, у: Приповетке Л. К. Лазаревића ... стр. 257. 
Резюме

В данной работе на основе анализа творчества Лазы Лазаревича, охватывающего новеллы, выделены различные виды юмора, выступающие в его рассказах. Автор приходит к выводу о зависимости типа юмора от способа повествования: в случае, когда повествователь рассказывает о собственных переживаниях (в рассказе Швабка и Ветер), встречается ироническое отношение к миру и к самому себе; в свою очередь повествователь, явлющийся участником или наблюдателем событий, использует юмор при описании ситуаций, героев (чаще второстепенных), а также словесный юмор (например, гиперболические сравнения, анимизацию и антропоморфизацию, употребление псевдоцитат и кавычек). Интертекстовой дискурс с романтизмом в рассказе Вертер писатель ведет, применяя пародийную стратегию. 